DOI 10.17150/978-5-7253-3001-4.48

В.Ю. БАНКУЕВ

УДК 325.2

ББК $66.4(4 / 8)$

\title{
АСПЕКТЫ «МЯГКОЙ СИЛЫ» В АДАПТАЦИОННЫХ СТРАТЕГИЯХ СОВРЕМЕННЫХ МОНГОЛЬСКИХ МИГРАНТОВ В СІІА И СТРАНАХ ЕВРОСОЮЗА
}

В статье анализируется институциализация монгольских диаспор в странах США и Евросоюза как стратегия адаптации и геополитический фактор «мягкой силы». На примерах деятельности эмигрантских 
культурных ассоциаций и обществ дружбы прослеживается формирование повестки сотрудничества и создание положительных образов Монголии в принимающих обществах.

Ключевые слова: внешние миграции, монгольские диаспоры, «мягкая сила», стратегия адаптации, культурные ассоциации, ламаизм, национальные праздники.

V.YU. BASHKUEV

\section{"SOFT POWER" ASPECTS OF THE ADAPTATION STRATEGIES OF MODERN MONGOLIAN MIGRANTS IN THE USA AND COUNTRIES OF THE EU}

The article analyzes institutionalization of Mongolian diasporas in USA and the EU member states as an adaptation strategy and geopolitical "soft power" factor. Using case studies of émigré cultural associations and friendship societies the article traces the shaping of cooperation agenda, as well as positive images of Mongolia in the recipient societies.

Keywords: external migration, Mongolian diasporas, "soft power", adaptation strategy, cultural associations, Lamaism, national holidays.

Ритм миграций по сей день определяет индивидуальные и коллективные жизненные стратегии монголов. Эта установка отражена в речи президента Монголии Н. Энхбаяра к 800-летию государственности (2006): «...Мы монголы — кочевой народ. Мы должны быть готовы к движению в любой момент. Переход к демократии для нас подобен миграции и перекочевке к новому пастбищу...» [6, с. 7]. Открывшиеся после заката социалистической эры миграционные возможности обусловили активный выезд монгольских граждан в США, Южную Корею, государства Европейского Союза. Сегодня, по прошествии тридцати лет с распада соцлагеря, монголы уже не открывают для себя мир, а стараются активно взаимодействовать с ним.

Как независимое мононациональное государство, Монголия старается сформулировать государственную политику по отношению к монгольским сообществам за рубежом. В декабре 2011 г. президент Монголии Ц. Элбэгдорж обратился к монголам мира с призывом возвратиться на родину, чтобы вместе развивать страну. Эмоциональный призыв ко всем тем, «у кого монгольская душа» транслировал заявление о том, что монголов миллионы и живут они по всему миру. Важен его подтекст мобилизация поддержки процессов развития внутри Монголии среди монгольских диаспор в развитых странах мира. Значительная часть их созидательного потенциала заключена в способности создавать и транслировать привлекательный образ «новой Монголии» в западный мир.

Важная геополитическая миссия монголов за рубежом - выстраивание стратегии «мягкой силы», способной добиться того, чего совре- 
менной Монголии не удастся достичь силой «жесткой». Эффект воздействия возлагается на уникальность и запоминаемость монгольской культуры, а также на гибкость и адаптивность монголов в информационном пространстве.

Одной из основных адаптационных стратегий монгольских мигрантов на западе является институциализация своих объединений в форме культурных ассоциаций или обществ дружбы. Речь идет о некоммерческих организациях, репрезентирующих монгольские сообщества на уровне государственных институтов принимающих стран, способных мобилизовать ресурсы культурной дипломатии и направить их на создание положительного образа страны, культуры и народа в обществе-реципиенте. Эта стратегия сопряжена с линией монгольского правительства на разработку культурной политики, транслирующей вовне образы Монголии как дружественной страны, исповедующей принципы открытого общества, демократии, религиозной и культурной толерантности, уважающей права человека и международные соглашения.

Такая политика одновременно является стратегией выживания. Монгольские общины слишком малочисленны, чтобы создавать и поддерживать этническую инфраструктуру - специализированные продуктовые магазины, рестораны, кафе и другие общественные места, помогающие консолидировать диаспору и представлять культуру мигрантов-монголов на уровне повседневности в принимающих странах. Например, на западном побережье США в районе Лос-Анджелеса сконцентрировано около 5000 монголов, составляющих самое крупное локальное монгольское сообщество в Америке [4]. Но и оно является слишком малочисленным для оказания сколь-нибудь действенного политического влияния даже в пределах своего муниципального округа. Попытки добиться в городском совете Лос-Анджелеса официального признания квартала «Маленькая Монголия» результатов не дали. Однако благодаря усилиям активистов, намеренных и дальше строить монгольскую общину в США, у лос-анджелесских монголов появились культурная ассоциация, монгольская школа, христианская церковь и буддийский храм [4].

Одной из старейших культурных ассоциаций монголов в США, и в целом на западе является «Монгольско-американская культурная ассоциация» (Mongolian-American Cultural Association, MACA), основанная в 1988 г. профессором Университета Индианы Гомбожабом Хангином и Цорж-ламой из монастыря Хорго в Южной Монголии [3, с. 37]. Организация способствует сохранению и популяризации уникальной истории и культуры всех монгольских народов, включая бурят, калмыков, тувинцев и монголов АРВМ КНР. В 1992 г. она была зарегистрирована как некоммерческая организация.

Как НКО ассоциация ведет большую гуманитарную работу в Монголии и США. Она поддерживала программы Корпуса мира в Монголии, организо- 
вывала благотворительные поставки инсулина, осуществляла помощь образованию. В 1995 г. МАСА был организован Монгольский детский фонд помощи и развития (Mongolian Children's Aid and Development Fund, MCADF), почетным директором которого был бывший Госсекретарь США Дж. Бейкер. С 1993 г. МАСА регулярно издает монгольский бюллетень «Монгол Толбо» и организует в США различные культурные мероприятия. Ассоциация имеет информативный Интернет-сайт по адресу http://www.maca-usa.org.

Необходимо упомянуть «Монгольский фонд культурного наследия» в Нью-Йорке, «Монгольский культурный центр» и «Монгольскую коллекцию в Библиотеке Конгресса» в Вашингтоне, союз монгольских женщин Америки «Соёл», «Объединение монголов Вашингтона», писательскую ассоциацию «Тулга» в Денвере [3, с. 38]. Особого внимания заслуживают тибетско-монгольские культурные организации, работающие в области буддизма и буддийской культуры.

Ассоциирование с тибетскими религиозными организациями обладает мультипликативным эффектом, используя который монгольские культурные сообщества не только значительно расширяют свою аудиторию и степень воздействия, но и получают новые возможности для фандрэйзинга и саморекламы. Большую роль здесь играет сочувствие к проблемам Тибета на западе, высокий моральный авторитет Его Святейшества Далай-ламы XIV и популярность ламаизма в США и ЕС. Значительный сегмент монгольской культуры приобщен к наследию буддизма и презентация монгольского мира как интегральной части буддийского мира, безусловно, является весомым дополнением к усилиям по продвижению образа Монголии в мире.

«Тибетско-монгольский буддийский культурный центр» (“The Tibetan Mongolian Buddhist Cultural Center") был основан как тибетский культурный центр в 1979 г. Тубтеном Жигме Норбу (Такцер Ринпоче) в Блумингтоне, штат Индиана. В 2007 г. Его Святейшество Далай-лама XIV расширил сферу деятельности организации и официально дал центру его сегодняшнее название. Центр возглавляет назначенный Его Святейшеством в 2005 г. достопочтенный Арья Ринпоче. «Тибетско-монгольский буддийский культурный центр» работает над сотрудничеством с официальными властями города Блумингтона, Университетом Индианы, религиозными концессиями, например, Братьями Доминиканцами в Католическом центре Св. Павла. Культурные мероприятия центра включают ежегодное проведение праздника Наадам, организацию тибетского и монгольского летних лагерей, благотворительных представлений для тибетской и монгольской молодежи, выставки тибетского и монгольского искусства. У центра есть информативный, регулярно обновляющийся Интернет-сайт по адресу www.tmbcc.org.

Информационную поддержку монгольской диаспоре в Северной Америке оказывает Tibet House US. Главой этой организации является американский буддолог, писатель и общественный деятель профессор 
Роберт Турман. На ее базе проводятся выставки современного монгольского искусства, концерты уникальных исполнителей монгольской национальной музыки. Организационные возможности «Тибет Хаус» позволяют создавать информационные поводы, привлекающие общественный интерес к монголам в американских средствах массовой информации. «Тибет Хаус» - мощная международная неправительственная организация, имеющая отделения в США, Европе и Азии (в том числе в Москве). Среди ее друзей и спонсоров - голливудские актеры Ричард Гир и Ума Турман, официальные представители Его Святейшества Далай-ламы XIV, известные ученые, политики, общественные деятели. Организация находится под непосредственным патронажем Его Святейшества Далай-ламы XIV Тензин Гьяцо [2].

В ЕС культурно-просветительской деятельностью выделяется австрийско-монгольское общество «Очир» (Österreichisch-Mongolische Gesselschaft "Otschir"), постоянно функционирующее в Вене. Общество «Очир» было основано в 1996 г. и является членом организации, объединяющей все общества дружбы Австрии с другими странами - $\mathrm{PaN}$. Миссия состоит в продвижении отношений между Монголией и Австрией, а также между народами этих стран на всех уровнях.

Большое значение уделяется культурным обменам и укреплению социальных связей между монголами и австрийцами, а также фрормированию и продвижению образа Монголии в Австрии. «Очир» знакомит австрийцев с историей, культурой и природой Монголии, но не оставляет в стороне и современных насущных проблем монголов. Общество помогает проживающим в Австрии монголам адаптироваться в стране, почувствовать в инокультурной и иноязычной среде частицу Монголии, ее культуры и истории.

В совет общества «Очир» входят как австрийцы, так и монголы. Среди членов совета и попечительского совета - ученые, общественные деятели, профрессора Венского университета, инженеры, военные. Координация работы общества проходит на различных уровнях. Некоторые организуемые мероприятия требуют правительственного уровня, другие являются местными и личными инициативами членов общества. Культурные мероприятия австрийско-монгольского общества «Очир» включают: публичные лекции о Монголии (например, семинар по материалам путешествия Клауса Хюбнера «Россия-Монголия на мотоцикле»); концерты исполнителей традиционной монгольской музыки и вокала ("Hosoo and Transmongolia" - концерт исполнителя горлового пения и лекция об искусстве «Хоомэй»); визит монгольского хамбо-ламы Шинэндэнцэл, настоятеля монастыря Жанчивдэчинлин в Улан-Баторе; и большое празднование «Наадам» в Бадене под Веной 4 июля 2015 г.

Как офрициально зарегистрированное общество дружбы, «Очир» уделяет особое внимание информационной составляющей своей де- 
ятельности. У общества есть профессионально созданный, регулярно обновляющийся Интернет-сайт по адресу www.mongolei.or.at. Благодаря современным технологиям связи, некоторые события передаются в прямой эфир через спутниковую связь и Интернет, а общество «Очир» организует их публичный просмотр с привлечением широкой публики. Так, 1 августа 2009 г. австрийско-монгольская команда, включавшая в себя двух членов правления Сэргэлэн Баясгалан и Михаэля Айзенриглера, вела прямую трансляцию из пустыни Гоби с места, где была найдена часть сокровищ Данзан Равжаа. Показ осуществлялся в венском кинотеатре "Schikanderkino." На событии присутствовали монгольские художники и деятели искусств [9].

Похожие мероприятия проводятся и в Германии с участием Посольства Монголии и общественных организаций. Дипломатические отношения между Федеративной Республикой Германией и Монголией были установлены в 1974 г. В Бонне было создано германо-монгольское общество, в рамках которого реализовывались культурные и научные программы. В Боннском университете по сей день существует одна из крупнейших на западе школ монголоведения. Ежегодное издание германо-монгольского общества «Mongolische Notizen» публикует текущий анализ монгольской политики, экономики и культуры, а также отчеты о реализующихся германо-монгольских проектах.

Существуют также несколько других монгольских и германо-монгольских ассоциаций. Одной из таких организаций является «Майдар», монгольская НКО в Берлине, работающая в области сохранения монгольского языка и культуры в Германии. Однако, как отмечает глава организации Алимаа Амгалан, современные монголы в Германии все меньше интересуются их деятельностью, потому что пытаются как можно сильнее интегрироваться в немецкое общество. Сообщество пока скрепляется некоторыми инициативами, например, в рамках Берлинского спортивного клуба «Tsog Mongol Sport Club» [7].

29 августа 2015 г. в рамках 35-й «Длинной ночи музеев» (“Lange Nacht der Museen") была организована выставка монгольского художника Ган-Эрдэнэ Цэнда, живущего и работающего в Германии. Кроме того, общественная монгольская организация «Майдар» из Берлина знакомила гостей выставки с традиционной монгольской юртой и национальными играми. В мероприятии принимали участие монгольские музыканты, игравшие на народных инструментах. Также был показан получасовой документальный фильм «Nomadic by Nature» [5].

Информационная деятельность обществ подобных «Очиру» и «Майдару» имеет большое значение не только для популяризации Монголии и приобщения западной публики к уникальной монгольской истории и культуре. Взаимодействие идет сразу по многим направлениям - культурному, религиозному, социально-политическому. Содер- 
жательные лекции, сопровождаемые профессиональным визуальным рядом, вызывают большой интерес и массу вопросов у аудитории, способствуют установлению новых контактов и реализации проектов в сфере науки, образования и культуры. В Монголию привлекается все большее количество австрийских и немецких туристов, стремящихся своими глазами увидеть то, с чем они познакомились в ходе мероприятий, организованных культурными организациями. Это - результат культурной дипломатии, язык и методы которой постоянно совершенствуются в работе институциализированных культурных сообществ.

Интересны информационные ресурсы монгольской диаспоры в Италии. По данным Международной организации по миграции количество монголов на Аппенинском полуострове невелико - всего 275 чел. (2016 г.). Тем не менее у них функционирует большой и информативный Интернет-портал www.mongolia.it на итальянском и монгольском языках. Он постоянно обновляется, имеет ссылки на вебсайт посольства Монгольской Республики в Италии со всей необходимой информацией для получения виз и планирования визитов из Италии в Монголию. Большое внимание уделяется образу Монголии, сложившемуся у итальянских путешественников. На сайте есть большая подборка путевых записок, дневников и наблюдений итальянских путешественников в Монголии (постсоветский период). По-видимому, итальянцы стремятся продолжать традиции Марко Поло и активно знакомятся с Монголией сами и через свои впечатления и наблюдения знакомят с этой страной своих соотечественников.

Как и в случае монголов в Австрии, важным фактором здесь является вовлеченность в работу с монгольской диаспорой итальянских энтузиастов и друзей Монголии. Сайт www.mongolia.it был создан в 2001 г. журналистом итальянской газеты «Corriere della Sera» Фредерико Пистоне. Как указано на сайте, Пистоне влюбился в эту загадочную и удивительную страну и посвятил ей свои работы - книги, репортажи, международные гуманитарные проекты. Больше половины редакционной коллегии сайта www.mongolia.it составляют итальянцы или постоянно проживающие в Италии монголы [8].

Италия, страна оперы и классической музыки, привлекает таланты со всего мира. Монголия не является исключением. Монголы музыкальны от природы и ряд монгольских вокалистов постоянно работает за границей, в том числе в Италии. Монгольская оперная певица Аяна Самбуу живет и работает там с 2003 г. Она исполняет широкий репертуар оперной классики от Россини до Моцарта, участвует в работе курсов исполнительского мастерства для профессионалов, представляет монгольскую культуру в Италии и пишет короткие рассказы. Аяна Самбуу входит в редколлегию сайта www.mongolia.it и постоянно пишет для него материалы. Ее история - одна из историй успеха монгольских мигрантов в Европейском Союзе [8]. 
В социальных сетях выложено большое количество видеоматериалов о монгольских национальных праздниках (Наадам, Цагаан Сар). Праздники имеют большое консолидирующее значение для монголоязычных диаспор по всему миру. Они не только собирают вместе рассеянных по странам Евросоюза и Северной Америки представителей монгольских этносов, но и демонстрируют принимающему обществу диаспору как спаянное единой традиционной культурой сообщество.

Национальные праздники также консолидируют друзей монгольской культуры, облегчая создание неформальных сетей и появление новых проектов. Именно во время крупных праздников общество принимающей страны непосредственно соприкасается с представителями монгольской традиционной культуры, воспринимает и учится ценить уникальную кочевую культуру. Этому способствуют и выбранные для проведения праздников места. Например, в Австрии летний военно-спортивный фестиваль Наадам традиционно проходит в районе Донауинзель - на искусственном острове посреди Дуная, излюбленном месте отдыха жителей Вены. А во Франции в 2011 г. праздник под названием «Европын Монголчуудын Наадам» проходил в местности Rubrouck, недалеко от г. Кале. Небольшой городок Рубрук является родиной Гильома де Рубрука, известного фламандского монаха-фрранцисканца, совершившего путешествие к монголам по поручению фрранцузского короля Людовика IX в 1253-1255 гг. Близость этой местности к Бельгии и Великобритании определила основной состав гостей и участников, представляющих восемь городов Франции, Бельгии, Великобритании, а также гостей из Чехии [1, с. 95-96].

Сегодня Монголия продолжает активную работу по продвижению своего образа в странах Европы. 18 октября 2014 г. в Центрально-Европейском университете состоялась лекция президента Монголии Ц. Элбэгдоржа «Переход Монголии к демократии и его уроки». Выступая в ЦЕУ, Элбэгдорж обращался к аудитории выпускников университета, многие из которых занимали и занимают ключевые позиции в странах Центральной Европы. Язык культурной дипломатии, которым пользуется Монголия как в выступлениях высших лиц государства, так и в деятельности культурных обществ и ассоциаций по всему миру, работает на созидательный образ страны и общепринятым современным средством межкультурной коммуникации на всех уровнях.

Основными промоутерами Монголии за рубежом остаются культурные организации, творческие коллективы и индивидуальные деятели культуры, постоянно живущие или часто гастролирующие в Северной Америке и Европе. Своим талантом и наработанными связями они насыщают социокультурную матрицу образа Монголии как страны загадочной и уникальной, еще не поглощенной глобализацией. Поддерживая этих «послов культуры» с их горизонтальными формальными и неформальными коммуникациями в странах проживания, Монголия сможет усилить 
опорные точки культурной дипломатии, привлекая все больше европейцев и американцев в ряды друзей и почитателей монгольской культуры.

Большое значение имеет формирование и продвижение историй успеха монгольских мигрантов, вносящих яркие штрихи в собирательный медиа-образ монголов за рубежом как талантливых и успешных представителей своего народа и страны.

Работа эта, в целом, продвигается успешно, о чем свидетельствует постоянный высокий интерес к Монголии среди европейских и американских путешественников, ученых и общественных деятелей. Однако даже институциализированным диаспоральным объединениям зачастую не хватает сил, масштаба, а главное, идеологического основания для широкой консолидации монголо-язычных диаспор мира.

\section{Список использованной литературы и источников}

1. Башкуев В. Ю. Монгольские диаспоры в Европе и Северной Америке: адаптация, институциализация, репрезентации / М. Н. Балдано, В. Ю. Башкуев, П. К. Варнавский, В. И. Дятлов, С. В. Кириченко, Б. З. Нанзатов, М. М. Содномпилова, Н. Галиймаа, Ш. Сони, З. Шмыт // Миграции и диаспоры в монгольском мире: стратегии и практики транскультурного взаимодействия. - Улан-Удэ : Изд-во Бурят. науч. центра СО РАН, 2017. - С. 52-127.

2. Офрициальный сайт «Тибет Хаус» [Электронный ресурс]. — Режим доступа : https://tibethouse.us/about/board-staff/.

3. Петрова М. П. Монгольское зарубежье: США / М. П. Петрова // Studia culturae. - 2013. — № 18. - C. 35-42.

4. Aghajanian L. Immigrants in Los Angeles Feeling Economic Pull of Homeland [Electronic resource] / Liana Aghajanian // Eurasianet.org. August 13, 2012. - URL : http://www.eurasianet.org/node/65779

5. Embassy of Mongolia in Germany [Electronic resource]. — URL : http://www. botschaft-mongolei.info/index. php?option=com

6. Jeffries I. Mongolia: A Guide to Economic and Political Developments / Ian Jeffries. — London ; New York : Routledge, 2007. — 207 p.

7. Mittwoch J., Kehrwald H. Modern Nomads [Electronic resource] / J. Mitt-woch, H. Kehrwald. — URL : http://expedition-heimat.dw.com/.php.

8. Mongolia.it [Electronic resource]. — URL : http://www.mon-golia.it

9. Österreichisch-Mongolische Gesselschaft "Otschir" [Electronic resource]. URL : http://www.mongolei.or.at.

\section{Информация об авторе}

Башкуев Всеволод Юрьевич — доктор исторических наук, ведущий научный сотрудник отдела истории, этнологии и социологии, Институт монголоведения, буддологии и тибетологии СО РАН, 670047, Улан-Удэ, ул. Сахьяновой, 6; e-mail: seva91@yahoo.com

\section{Author}

Vsevolod Yu. Bashkuev - Doctor of History, Leading Research Fellow, Department of History, Ethnology and Sociology, Institute of Mongolian, Buddhist and Tibetan Studies, Russian Academy of science, Siberian Branch, 6 Sakhyanova St., 670047, Ulan-Ude, Russia; e-mail: seva91@yahoo.com 